Article

\title{
Energy Recovery from Wastewater Treatment Plants in the United States: A Case Study of the Energy-Water Nexus
}

\author{
Ashlynn S. Stillwell ${ }^{1}{ }_{*}$, David C. Hoppock ${ }^{2}$ and Michael E. Webber ${ }^{3}$
}

1 Department of Civil, Architectural, and Environmental Engineering, The University of Texas at Austin, 1 University Station C1786, Austin, TX 78712, USA

2 Climate Change Policy Partnership, Duke University, Box 90335, Durham, NC 27708, USA;

E-Mail: david.hoppock@duke.edu

3 Department of Mechanical Engineering, The University of Texas at Austin, 1 University Station C2200, Austin, TX 78712, USA; E-Mail: webber@mail.utexas.edu

* Author to whom correspondence should be addressed; E-Mail: ashlynn.stillwell@mail.utexas.edu; Tel.: +1-512-475-6867; Fax: +1-512-471-5870.

Received: 1 February 2010; in revised form: 10 March 2010 / Accepted: 30 March 2010 /

Published: 5 April 2010

\begin{abstract}
This manuscript uses data from the U.S. Environmental Protection Agency to analyze the potential for energy recovery from wastewater treatment plants via anaerobic digestion with biogas utilization and biosolids incineration with electricity generation. These energy recovery strategies could help offset the electricity consumption of the wastewater sector and represent possible areas for sustainable energy policy implementation. We estimate that anaerobic digestion could save 628 to 4,940 million kWh annually in the United States. In Texas, anaerobic digestion could save 40.2 to 460 million $\mathrm{kWh}$ annually and biosolids incineration could save 51.9 to 1,030 million kWh annually.
\end{abstract}

Keywords: wastewater; energy; biogas; biosolids incineration; energy recovery; policy 


\section{Nomenclature}
CWNS:
Clean Watershed Needs Survey
EPA:
Environmental Protection Agency
EPRI:
Electric Power Research Institute
mgd:
million gallons per day
TCEQ:
Texas Commission on Environmental Quality

\section{Introduction}

Wastewater treatment plants represent a portion of the broader nexus between energy and water [1]. Collecting, treating, and discharging municipal wastewater to acceptable permit standards requires energy, mostly as electricity, but also as natural gas or other fuels. Nationwide, wastewater treatment represents 0.1 to $0.3 \%$ of total energy consumption and within local city and community government, water and wastewater treatment operations are often the largest consumer of energy [2]. Furthermore, energy for wastewater treatment is likely to increase in the future due to increasing population, stricter discharge requirements, and aging infrastructure. Possible future standards for removal of currently-unregulated contaminants, such as pharmaceuticals and personal care products, might require significant increases in energy consumption at wastewater treatment plants [3,4].

Fortunately, most wastewater treatment facilities can significantly reduce their energy costs, by up to $30 \%$ or more, through energy efficiency measures and treatment process modifications [5]. Through optimized aeration and improved pumping alone, wastewater treatment plants could save 547 to 1,057 million $\mathrm{kWh}$ annually, reducing overall energy use in the wastewater sector by 3 to $6 \%$ [6].

Wastewater treatment process modifications considered in this case study include anaerobic digestion with biogas utilization and biosolids incineration with electricity generation. Our analysis provides a top-level estimate of energy savings within the wastewater sector in the United States via these two process modifications. We first examine potential energy recovery from anaerobic digestion with biogas utilization on a national scale. Since the state of Texas produces and consumes more electricity than any other state in the nation, we then use Texas as a testbed for analysis of energy recovery from biosolids incineration with electricity generation. These energy recovery strategies could help offset the electricity consumption of the wastewater sector and represent possible areas for sustainable energy policy implementation. Our analysis considers energy consumption and potential savings only; the economics of energy recovery from wastewater treatment, while highly relevant, is reserved for a separate analysis.

Energy recovery at wastewater treatment plants represents an important policy lever for sustainability. However, to the best of our knowledge, no one has ever created a model of its potential. This work fills that gap. 


\section{Background}

\subsection{Anaerobic Digestion with Biogas Utilization}

Wastewater treatment processes chemically, physically, and biologically treat raw municipal sewage and separate wastes into a liquid effluent stream, which is usually discharged to a receiving water body, and solid-liquid streams of debris and sludge [7]. Prior to reuse or disposal, wastewater sludge must be treated to reduce odors and disease-causing agents such as pathogens and bacteria. Treated sludge is then referred to as biosolids. Biosolids have high water content and typically are dewatered prior to further treatment or disposal. Some municipal wastewater treatment plants incinerate dewatered biosolids as a means of disposal, which requires dewatering prior to incineration. Other biosolids management methods include use as fertilizers or soil stabilizers or disposal in a landfill [8,9].

Sludge is usually treated to form biosolids using some form of digestion. Sludge digestion and the associated solids processing operations constitute the second largest use of electricity in wastewater treatment [10]. Aerobic digestion processes use oxygen, either from air or in pure form, to facilitate microorganism digestion of solids, pathogens, and bacteria, forming carbon dioxide and biosolids among the products. The energy-intensity of blowers and aerators makes aerobic digestion a large energy consumer, yet aerobic digestion is commonly used in practice due to ease of aerobic operations $[9,10]$. Anaerobic digestion processes, on the other hand, facilitate digestion in the absence of oxygen, forming methane-containing biogas and biosolids as products. Biogas produced from anaerobic digestion is a possible fuel source for digester heating or electricity generation [2,9]. Previous research by the scientific community has analyzed the mass balance of organic material throughout wastewater treatment operations [11], carbon sequestration via municipal wastewater treatment [12], and energy recovery from anaerobic digestion and biosolids incineration at pulp and paper mill wastewater operations [13].

Optimized anaerobic digestion occurs in two temperature ranges, mesophilic, 32 to $35{ }^{\circ} \mathrm{C}$, and thermophilic, 50 to $57{ }^{\circ} \mathrm{C}$, thus digester heating might be necessary in some climates. In these temperature ranges, anaerobic digestion produces biogas containing 40 to $75 \%$ methane, with a balance of primarily carbon dioxide and other compounds, with $60 \%$ methane as a typical composition. As a rule of thumb, anaerobic digestion produces about $35 \mathrm{~m}^{3}$ of gas per day per person in the service area, which has a typical heating value of approximately $6.2 \mathrm{kWh} / \mathrm{m}^{3}$ [14]. Biogas also contains water vapor and small amounts of siloxanes and hydrogen sulfide, which must be removed before the biogas can be used as a fuel for electricity generation to prevent damage to the generation equipment [14].

Electricity generation using biogas from anaerobic digestion varies depending on the generation technology employed. Research from Burton and the Electric Power Research Institute (EPRI) shows that anaerobic digestion with biogas utilization can produce about $350 \mathrm{kWh}$ of electricity for each million gallons of wastewater treated at the plant [10]. The Environmental Protection Agency (EPA) Combined Heat and Power Partnership estimates that approximately $491 \mathrm{kWh}$ of electricity can be produced with a microturbine and $525 \mathrm{kWh}$ of electricity can be produced with an internal combustion engine for each million gallons of wastewater treated at a plant with anaerobic digestion [14]. Research shows that wastewater treatment plants with treatment capacities less than 5 million gallons per day 
(mgd) $\left(18,900 \mathrm{~m}^{3} / \mathrm{d}\right)$ do not produce enough biogas to make electricity generation feasible or cost-effective [14].

\subsection{Biosolids Incineration with Electricity Generation}

After municipal wastewater sludge has been digested to form biosolids, wastewater facilities must dispose or reuse biosolids. The most common methods of biosolids disposal are landfilling, land spreading, and composting due to cost effectiveness; incineration is an alternative, more costly disposal method. Since biosolids contain reduced quantities of the harmful bacteria and pathogens destroyed during digestion, EPA policy (40 CFR Part 503) encourages beneficial use of biosolids, defined as use of biosolids as a fertilizer or soil amendment [15]. As a result of this EPA policy, land spreading and composting are federally-preferred methods of disposing biosolids, yet "procedures that derive energy from biosolids or convert them to useful products" are also acceptable [15]. Similar sewage sludge directives from the European Commission encourage agricultural use of treated wastewater sludge and set standards to minimize health risks and limit metals concentrations in soil [16]. Biosolids incineration with electricity generation is an effective biosolids disposal operation with potential for significant energy recovery.

Two equipment options are commercially available for biosolids incineration: multiple hearth furnaces and fluidized bed furnaces. Multiple hearth furnaces burn biosolids in multiple stages, allowing for hot air recycle to dry incoming biosolids and improve heat generation by reducing incoming moisture. While multiple hearth furnaces can be operated intermittently, continuous operation is preferred [17]. Fluidized bed furnaces are a newer technology that is more efficient, stable, and easier to operate than multiple hearth furnaces, but are limited to continuous operation only [17]. Both incineration technologies require cleaning of exhaust gases to prevent emissions of odor, particulates, nitrogen oxides, acid gases, hydrocarbons, and heavy metals [9,17]. Using either multiple heart or fluidized bed furnaces, biosolids incineration can be used to power a steam cycle power plant, where heat from incineration is transferred to steam that turns a turbine connected to a generator, producing electricity. Reliable electricity generation that does not depend heavily on auxiliary fuels requires large amounts of biosolids, making incineration suitable for medium to large wastewater treatment plants [9].

Biosolids incineration has the advantage of achieving maximum solids reduction with energy recovery, in addition to producing a stable waste material as ash and requiring small amounts of land. Disadvantages include high capital investments, potentially high operations costs depending on auxiliary fuel use, operational difficulty, air emissions from combustion that might limit use in non-attainment areas, and possible public aversion [17]. Despite these disadvantages, biosolids incineration with electricity generation is an innovative approach to managing both water and energy. For example, the Hartford Water Pollution Control Facility in Hartford, CT, is incorporating an energy recovery facility into furnace upgrade projects and anticipates that biosolids incineration will generate $40 \%$ of the plant's annual electricity consumption [18]. Energy recovery potential of this magnitude makes biosolids incineration with electricity generation a feasible energy management strategy for wastewater treatment plants. 


\section{United States and Texas as Case Studies}

The United States and Texas are representative case studies for the energy recovery potential from wastewater treatment plants through anaerobic digestion with biogas utilization and biosolids incineration with electricity generation. Looking at the United States as a whole provides a large-scale testbed of the potential for energy recovery through implementation of federal policies or incentives as a part of a broader sustainability effort. On a smaller scale, the model of Texas illustrates possible energy savings through focused state policies.

Like the rest of the United States, municipal wastewater treatment plants in Texas are concentrated in or near urban population centers, as shown in Figure 1. These wastewater facilities consume electricity during operations, ranging from 670 to $2,950 \mathrm{kWh} / 10^{6}$ gal $\left(0.177\right.$ to $\left.0.779 \mathrm{kWh} / \mathrm{m}^{3}\right)$, but also have potential to generate electricity through various energy recovery and efficiency projects [19]. Energy recovery from wastewater treatment plants might offset facilities' electricity use or help power electric grids in the area.

Figure 1. Municipal wastewater treatment plants in Texas are concentrated in urban and suburban areas. Over $76 \%$ of Texas wastewater facilities treat flows of 1 million gallons per day $(\mathrm{mgd})\left(3,790 \mathrm{~m}^{3} / \mathrm{d}\right)$ or less; facilities treating over $50 \mathrm{mgd}\left(189,000 \mathrm{~m}^{3} / \mathrm{d}\right)$ are located in Austin, Houston, San Antonio, Dallas, and Fort Worth [21,22].

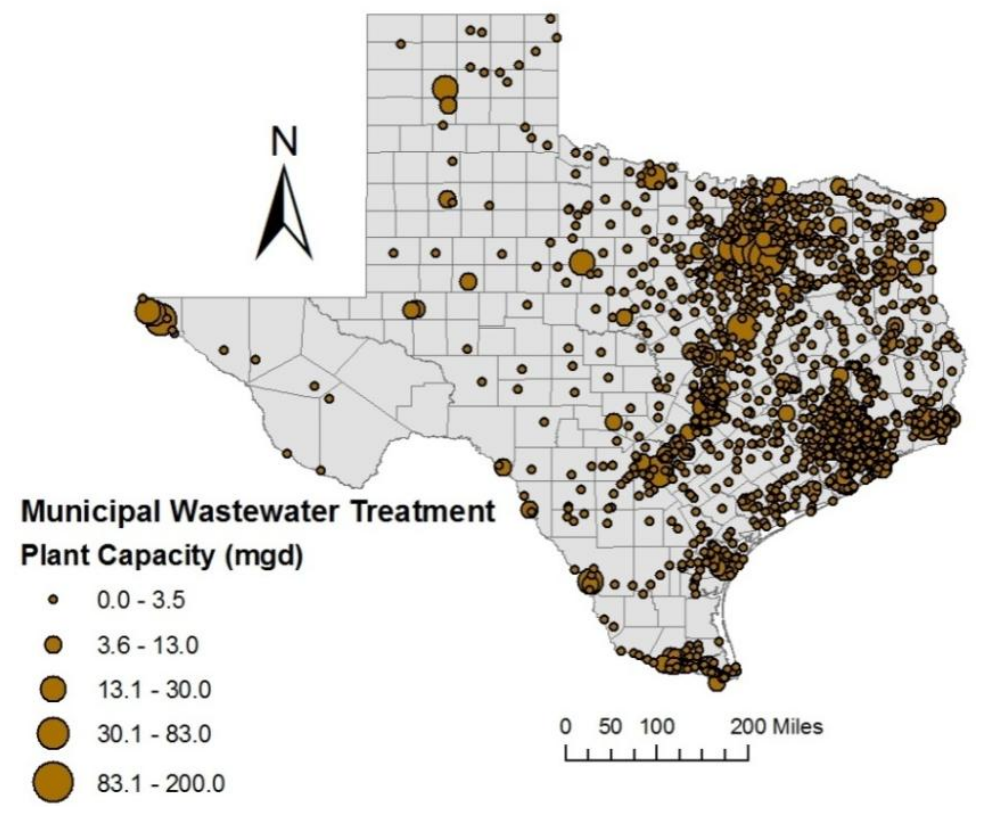

\section{Data and Assumptions}

Resource and energy data with geographic resolution are necessary for this assessment. Our analysis utilizes data collected by the U.S. EPA on a quadrennial basis, along with energy factors reported in literature. While these EPA data efficiently describe U.S. wastewater treatment plants, they are also limited in their content, depend on plant operator reporting, and mix systems of units (i.e., English and SI units). Consequently, we report mixed and SI units in this study to be consistent with conventional industrial notation. 
Analysis of energy recovery potential from wastewater treatment plants was completed using the following data:

- EPA Clean Watershed Needs Survey (CWNS) [20]-This EPA database contains data describing wastewater treatment facilities, including treatment flow capacity and unit operations used during treatment.

- Energy for Wastewater Treatment Operations [19,21,22]—Energy use at wastewater treatment plants was estimated based on data from the Electric Power Research Institute (EPRI) regarding wastewater treatment operations and the Texas Commission on Environmental Quality (TCEQ) and the U.S. EPA regarding Texas wastewater treatment plants. See the Appendix for tables of energy consumption for wastewater treatment.

- Energy Recovery from Biogas Utilization [10]—Ranges of energy recovery due to biogas utilization were based on data presented by Burton and EPRI.

- Energy Recovery from Biosolids Incineration [9,23]-Ranges of energy recovery due to biosolids incineration were based on reported typical dry solids content in wastewater, heating values of biosolids, and heat rates for steam electric power plants.

To model wastewater treatment in the United States and Texas, only municipal wastewater treatment plants were analyzed due to their reporting in the CWNS database and treatment of domestic waste with organic contents suitable for anaerobic digestion and biosolids incineration. Industrial wastewater treatment facilities usually have small treatment capacities (less than $5 \mathrm{mgd}\left(18,900 \mathrm{~m}^{3} / \mathrm{d}\right)$ ) and treat waste with specialized contaminants, such as heavy metals, that are not optimal for anaerobic digestion and biosolids incineration. Private wastewater facilities represent a small percentage of total wastewater treatment capacity and generally are not reported in current data sources. Consequently, industrial and private wastewater facilities were excluded from this analysis.

\section{Methodology}

\subsection{Anaerobic Digestion with Biogas Utilization}

Analysis of energy recovery potential for wastewater treatment plants using anaerobic digestion with biogas utilization was based on CWNS data and biogas energy factors reported by Burton and EPRI [10,20]. Potential energy recovery was calculated using Equation 1 below.

$$
E R_{\text {anaerobic }}=Q \times B E F
$$

In Equation 1, ER anaerobic represents energy recovery from anaerobic digestion $(\mathrm{kWh} / \mathrm{d}), Q$ represents the wastewater flow rate (mgd), and $B E F$ represents the biogas energy factor $\left(\mathrm{kWh} / 10^{6} \mathrm{gal}\right)$. Reported biogas energy factors range from 350 to $525 \mathrm{kWh} / 10^{6}$ gal $\left(0.0925\right.$ to $\left.0.139 \mathrm{kWh} / \mathrm{m}^{3}\right)$ for treated wastewater flows greater than $5 \mathrm{mgd}$, as shown in Figure $2[10,14]$. 
Figure 2. Potential energy recovery $(\mathrm{kWh} / \mathrm{d})$ from anaerobic digestion with biogas utilization varies with the biogas energy factor, $B E F\left(\mathrm{kWh} / 10^{6} \mathrm{gal}\right)$, and increases with increasing wastewater flow.

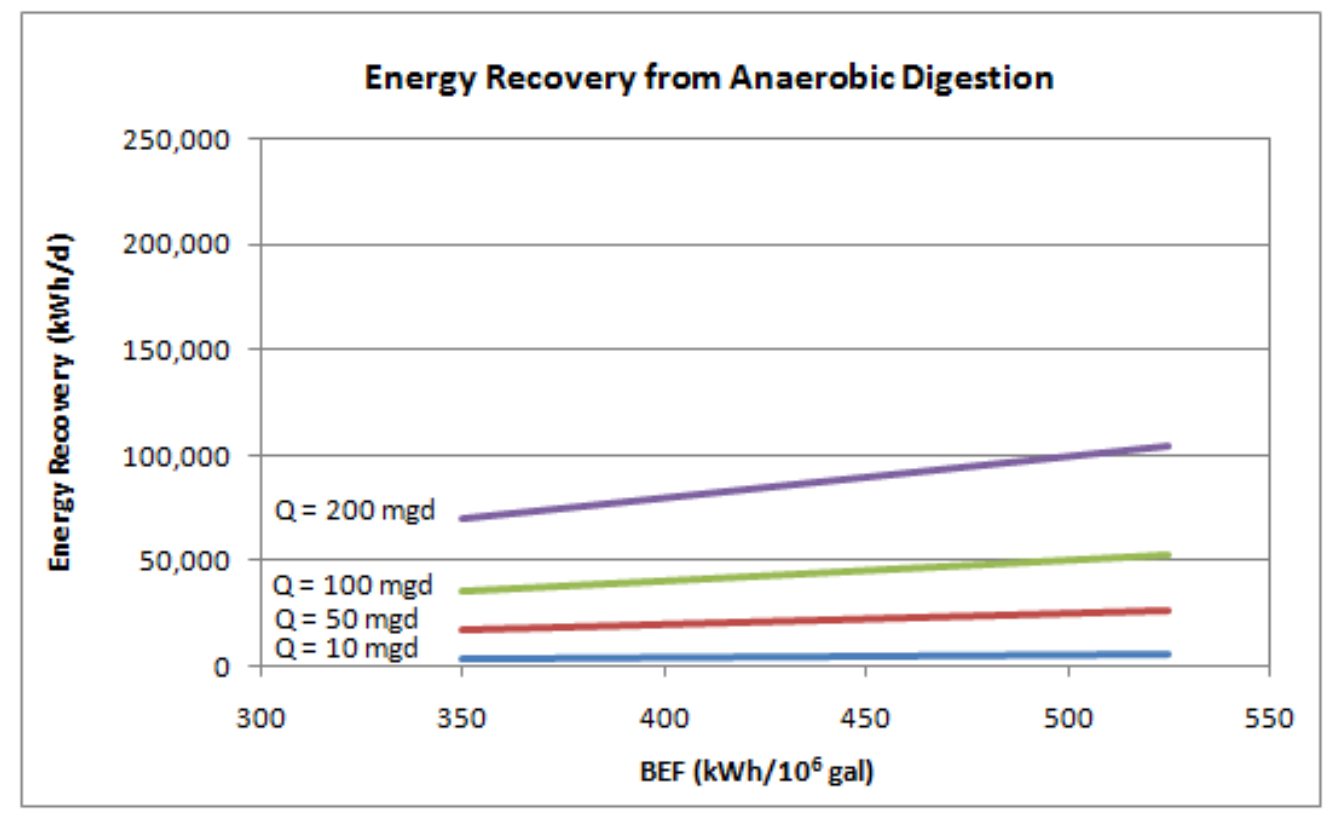

Energy recovery from anaerobic digestion with biogas utilization was calculated for three cases, for both the United States and Texas:

- Case AD-1: Baseline - The baseline energy recovery estimate includes all existing wastewater treatment plants that are already using anaerobic digestion with biogas utilization. For Case AD-1, we assume none of the biogas currently produced from anaerobic digestion is utilized for electricity generation. While some wastewater treatment plants utilize biogas (for digester heating or combined heat and power), most do not and instead flare the biogas. Since the CWNS survey data do not specify how wastewater treatment plants utilize biogas, our assumption provides a reasonable baseline for anaerobic digestion with biogas utilization for electricity generation [24].

- Case AD-2: Utilize existing biogas-This scenario represents energy recovery if all wastewater treatment plants currently using anaerobic digestion utilize the biogas produced, estimated for a $B E F$ range of 350 to $525 \mathrm{kWh} / 10^{6}$ gal $\left(0.0925\right.$ to $\left.0.139 \mathrm{kWh} / \mathrm{m}^{3}\right)$ [10,14]. Many wastewater treatment plants that utilize anaerobic digestion currently flare off the produced biogas. Case AD-2 reflects the energy recovery possible from utilizing the biogas currently produced instead of disposing by flaring. Only wastewater facilities treating at least $5 \mathrm{mgd}\left(18,900 \mathrm{~m}^{3} / \mathrm{d}\right)$ were included in this scenario due to biogas utilization cost-effectiveness, as discussed previously.

- Case AD-3: All wastewater treatment plants utilize biogas - This scenario represents the full potential of anaerobic digestion with biogas utilization, estimated for a $B E F$ range of 350 to $525 \mathrm{kWh} / 10^{6} \mathrm{gal}\left(0.0925\right.$ to $\left.0.139 \mathrm{kWh} / \mathrm{m}^{3}\right)$ [10,14]. In Case AD-3, all wastewater treatment plants treating at least $5 \mathrm{mgd}\left(18,900 \mathrm{~m}^{3} / \mathrm{d}\right)$ were modeled as implementing anaerobic digestion with biogas utilization. The minimum of $5 \mathrm{mgd}\left(18,900 \mathrm{~m}^{3} / \mathrm{d}\right)$ represents sufficient flow for cost-effective and feasible electricity generation [14]. 
These three cases illustrate the range of energy recovery possible through anaerobic digestion with biogas utilization, with Case AD-1 representing current operations and Case AD-3 showing the full potential of energy recovery from this approach.

\subsection{Biosolids Incineration with Electricity Generation}

Analysis of energy recovery potential for wastewater treatment plants using biosolids incineration with electricity generation was based on CWNS data, typical wastewater dry solids content, heating values of biosolids, and heat rates for steam electric power plants [9,20,23]. Potential energy recovery was calculated using Equation 2 below.

$$
E R_{\text {incineration }}=\frac{Q \times C_{s} \times H V}{H R}
$$

In Equation 2, ER incineration represents energy recovery from biosolids incineration $(\mathrm{kWh} / \mathrm{d}), Q$ represents the wastewater flow rate $(\mathrm{mgd}), C_{S}$ represents the wastewater dry solids content $\left(\mathrm{kg} / 10^{6} \mathrm{gal}\right)$, $H V$ represents the biosolids heating value $(\mathrm{kJ} / \mathrm{kg})$, and $H R$ represents the steam electric heat rate $(\mathrm{kJ} / \mathrm{kWh})$. The source did not specify whether $H V$ represented lower heating value or higher heating value, yet this heating value does account for residual moisture present in biosolids, dewatered to $28 \%$ solids or greater $[9,25]$. Since additional heat energy is used to evaporate remaining moisture in the biosolids, removing excess water is important for efficient electricity generation. A heat rate, $H R$, similar to that of a coal-fired power plant was used due to the solid fuel nature of biosolids and the associated air pollution control equipment [23]. Reported values for the factors in Equation 2 are shown in Table 1.

Potential energy recovery calculated using Equation 2 varies with the range in biosolids heating values reported in Table 1. For a constant steam electric heat rate and average dry solids content, energy recovery increases with wastewater flow as shown in Figure 3. Comparing Figure 2 and Figure 3, we show that for a given flow rate, $Q$, energy recovery from biosolids incineration with electricity generation is approximately twice that from anaerobic digestion with biogas utilization, on average.

Table 1. Energy recovery from biosolids incineration with electricity generation was calculated based on reported values.

\begin{tabular}{|l|c|c|c|c|}
\hline \multicolumn{1}{|c|}{ Factor } & Equation Term & Reported Value & Units & Reference \\
\hline Wastewater dry solids content & $C_{S}$ & $\begin{array}{c}680-1,020 \\
(0.180-0.269)\end{array}$ & $\begin{array}{c}\mathrm{kg} / 10^{6} \mathrm{gal} \\
\left(\mathrm{kg} / \mathrm{m}^{3}\right)\end{array}$ & {$[9]$} \\
\hline $\begin{array}{l}\text { Biosolids heating value } \\
\text { (Digested biosolids) }\end{array}$ & $H V \dagger$ & $9,000-14,000$ & $\mathrm{~kJ} / \mathrm{kg}$ & {$[9]$} \\
\hline Steam electric heat rate & $H R \ddagger$ & 10,550 & $\mathrm{~kJ} / \mathrm{kWh}$ & {$[23]$} \\
\hline
\end{tabular}

$\dagger$ Source did not specify lower heating value versus higher heating value.

$\$$ Heat rate similar to that of a coal-fired power plant due to the solid fuel nature of biosolids and associated air pollution control equipment. 
Figure 3. Potential energy recovery from biosolids incineration varies with the biosolids heating value, $H V$, and increases with increasing wastewater flow.

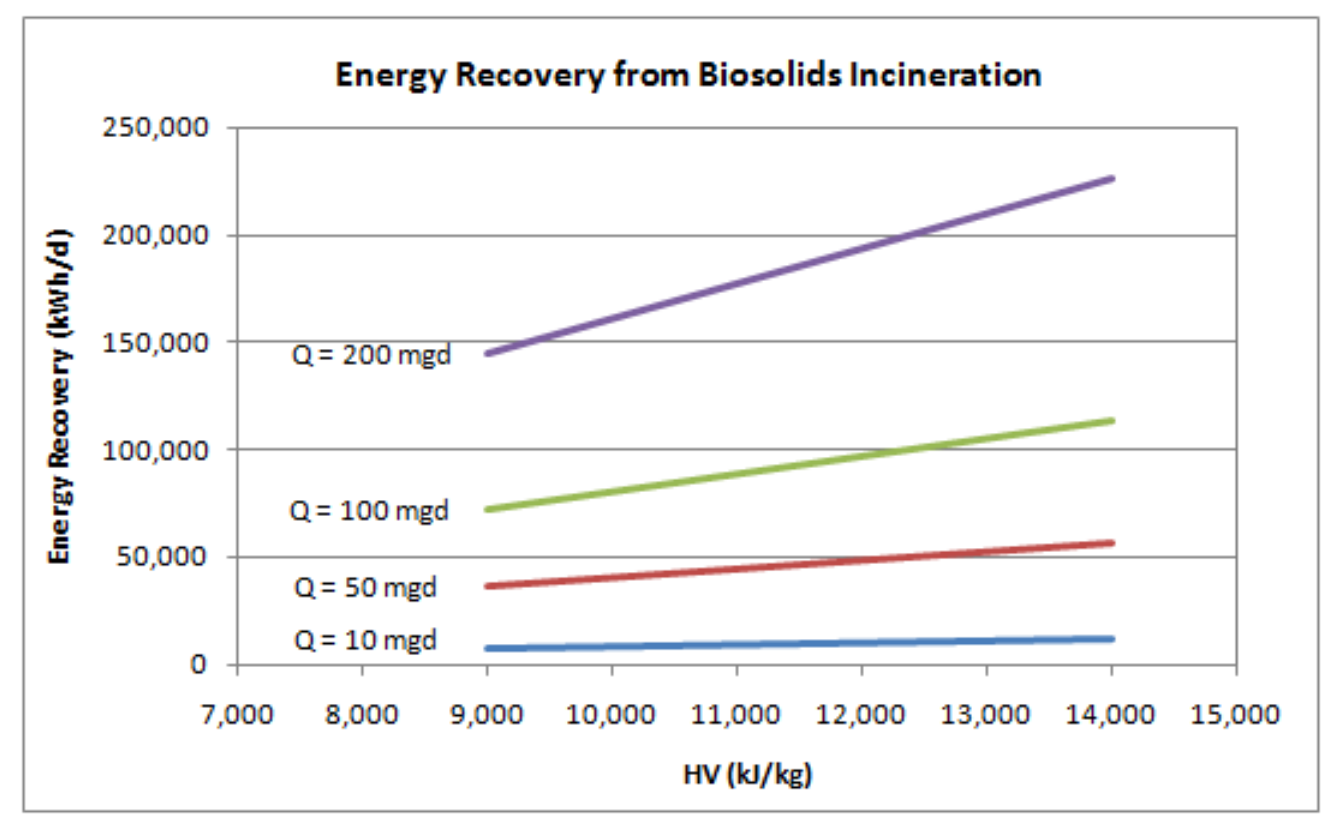

Most wastewater treatment plants with multiple hearth or fluidized bed furnaces use incineration as a means of biosolids disposal only and not for electricity generation. Thus this incineration represents an opportunity to generate electricity via a steam cycle. Energy recovery from biosolids incineration with electricity generation was calculated for two cases for Texas:

- Case BI-1: Utilize existing incineration processes - This scenario represents energy recovery if Texas wastewater treatment plants currently using biosolids incineration utilized the heat generated during incineration for a steam electric power plant.

- Case BI-2: All wastewater treatment plants implement incineration processes - This scenario represents the full potential of biosolids incineration with electricity generation. In Case BI-2, all wastewater treatment plants treating at least $5 \mathrm{mgd}\left(18,900 \mathrm{~m}^{3} / \mathrm{d}\right)$ were modeled as implementing biosolids incineration with electricity generation. A minimum flow rate of $5 \mathrm{mgd}\left(18,900 \mathrm{~m}^{3} / \mathrm{d}\right)$ was selected due to the relatively large amount of biosolids necessary to make incineration with electricity generation feasible without significant dependence on auxiliary fuel.

These two case studies represent the potential for biosolids incineration with electricity generation in Texas. While no Texas wastewater treatment plants report electricity generation from biosolids incineration, these two cases show potential energy recovery if such biosolids disposal methods were implemented widely.

\section{Results}

Based on data from CWNS and Equations 1 and 2, potential energy recovery from wastewater treatment plants was calculated for anaerobic digestion with biogas utilization and biosolids incineration with electricity generation. The results of these calculations are shown in Table 2. 
Table 2. Energy recovery estimates from anaerobic digestion with biogas utilization (Cases AD-1 through AD-3) and biosolids incineration with electricity generation (Cases BI-1 through BI-2) show significant potential for reducing energy consumption in wastewater treatment plants.

\begin{tabular}{|l|c|c|c|c|}
\hline \multirow{2}{*}{ Scenario } & \multicolumn{2}{|c|}{$\begin{array}{c}\text { Applicable Flow } \\
\text { mgd } \\
\left.\text { (million } \mathbf{~ m}^{\mathbf{3}} / \mathbf{d}\right)\end{array}$} & \multicolumn{2}{c|}{$\begin{array}{c}\text { Calculated Energy Recovery } \\
\mathbf{1 0}^{\mathbf{6}} \mathbf{~ k W h} / \mathbf{y r}\end{array}$} \\
\cline { 2 - 5 } & United States & Texas & United States & Texas \\
\hline Case AD-1: Baseline & $\begin{array}{c}4,918 \\
(18.6)\end{array}$ & $\begin{array}{c}315 \\
(1.19)\end{array}$ & $628-942$ & $40.2-60.4$ \\
\hline $\begin{array}{l}\text { Case AD-2: Utilize existing } \\
\text { biogas }\end{array}$ & $\begin{array}{c}18,184 \\
(68.8)\end{array}$ & $\begin{array}{c}1,086 \\
\left(4.11 \times 10^{6}\right)\end{array}$ & $2,320-3,480$ & $139-208$ \\
\hline $\begin{array}{l}\text { Case AD-3: All wastewater } \\
\text { treatment plants utilize biogas }\end{array}$ & $\begin{array}{c}25,796 \\
(97.6)\end{array}$ & $\begin{array}{c}2,401 \\
(9.09)\end{array}$ & $3,300-4,940$ & $307-460$ \\
\hline $\begin{array}{l}\text { Case BI-1: Utilize existing } \\
\text { incineration processes }\end{array}$ & Not calculated & $\begin{array}{c}189 \\
(0.715)\end{array}$ & Not calculated & $51.9-80.8$ \\
\hline $\begin{array}{l}\text { Case BI-2: All wastewater } \\
\text { treatment plants implement } \\
\text { incineration processes }\end{array}$ & Not calculated & $\begin{array}{c}2,401 \\
(9.09)\end{array}$ & Not calculated & $661-1,030$ \\
\hline
\end{tabular}

Note: U.S. estimates based on [10,14,20]. Texas estimates based on $[9,10,20,23]$.

Using 2004 CWNS data and EPRI energy factors, total electricity consumption for wastewater treatment in the United States was estimated at 18,100 to 23,800 million kWh per year [19,20]. Based on Cases AD-1 through AD-3, incorporating anaerobic digestion with biogas utilization into wastewater treatment facilities could decrease overall electricity use for the U.S. wastewater sector by 2.6 to $27 \%$, depending on the degree of implementation. The large spread in percentage of electricity savings in the U.S. wastewater sector is due to the range of wastewater flows (from 4,918 to $25,796 \mathrm{mgd}$ ( 18.6 to 97.6 million $\mathrm{m}^{3} / \mathrm{d}$ ) in Table 2 above) analyzed in Cases AD- 1 through AD-3 for the United States; the large range in wastewater flow leads to a large range of energy recovery from anaerobic digestion. The lower end of this range also assumes all wastewater treatment plants that currently produce biogas do not utilize it for electricity generation, as discussed previously.

Similar electricity consumption estimates were completed for Texas, totaling 1,800 to 1,950 million $\mathrm{kWh}$ per year [19-22]. Implementation of anaerobic digestion with biogas utilization, modeled in Cases AD-1 through AD-3, could decrease electricity use for Texas wastewater treatment facilities by 2.1 to $26 \%$. On-site electricity generation from biosolids incineration, modeled in Cases BI-1 and BI-2, could decrease electricity use by 2.7 to $57 \%$ in the Texas wastewater sector. Combining these two treatment and disposal operations, Texas could reduce electricity consumption for wastewater treatment plants by 4.7 to $83 \%$. These broad ranges represent varying degrees of implementation of energy recovery operations within the wastewater sector. Similar to the U.S. energy recovery estimate above, a wide range of wastewater flows were analyzed for Texas, ranging from 189 to $2,401 \mathrm{gpm}\left(0.715\right.$ to 9.09 million $\left.\mathrm{m}^{3} / \mathrm{d}\right)$ shown in Table 2 . This wide range of wastewater flows leads to a wide range of energy recovery estimates for both anaerobic digestion and biosolids incineration. 
Contrasting the potential from anaerobic digestion with biogas utilization to biosolids incineration with electricity generation in Texas, differences arise in energy recovery magnitudes and associated wastewater treatment plants. For example, Cases AD-2 and BI-1 represent energy recovery from utilizing existing wastewater facilities with anaerobic digestion and biosolids incineration, respectively. While the range of potential energy recovery is higher for anaerobic digestion at 139 to 208 million $\mathrm{kWh} / \mathrm{yr}$ than that for biosolids incineration at 51.9 to 80.8 million $\mathrm{kWh} / \mathrm{yr}$, the numbers of wastewater treatment plants with existing facilities are also significantly different: 41 wastewater treatment plants (treating over $5 \mathrm{mgd}\left(18,900 \mathrm{~m}^{3} / \mathrm{d}\right)$ ) with anaerobic digestion versus 5 plants with biosolids incineration. Comparing the results of Cases AD-3 and BI-2 with identical wastewater flows, both of which include all Texas wastewater plants treating $5 \mathrm{mgd}\left(18,900 \mathrm{~m}^{3} / \mathrm{d}\right)$ or more, shows that widely implementing biosolids incineration with electricity generation leads to significantly greater energy recovery than from anaerobic digestion with biogas utilization: 661 to 1,030 million $\mathrm{kWh} / \mathrm{yr}$ for biosolids incineration versus 307 to 460 million $\mathrm{kWh} / \mathrm{yr}$ for anaerobic digestion. This difference is due primarily to the larger heating value, $H V$, for biosolids incineration versus biogas energy factor, $B E F$, for anaerobic digestion. That is, biosolids have more inherent energy than biogas when used to generate electricity.

\section{Policy Implications}

Wastewater treatment plants can substantially reduce grid electricity consumption, especially by utilizing biogas from anaerobic digestion and heat from biosolids incineration to generate electricity. With increasing population, stricter discharge requirements, and aging infrastructure, as well as rising energy prices and concerns about climate change, wastewater treatment plants face many challenges that could significantly increase energy use and costs. For example, removal of emerging contaminants, such as pharmaceuticals and personal care products, might require significant increases in electricity consumption for wastewater treatment $[3,4]$.

In addition to reduced energy consumption, anaerobic digestion with biogas utilization and biosolids incineration with electricity generation at wastewater treatment plants could reduce greenhouse gas emissions by decreasing the amount of grid electricity required for operations. When compared to coal-fired power plants, digester biogas utilization and biosolids incineration (with appropriate air emissions control) produce fewer greenhouse gas and criteria air pollutant emissions. Life cycle air emissions from biosolids incineration might increase or decrease when considering the alternative use as fertilizer. These life cycle emissions, including fugitive biogas emissions that can negatively impact the carbon footprint, and energy consumption are reserved for future study.

Fully utilizing biogas to generate electricity, as in Case AD-2, might significantly reduce or reverse future growth in energy needs for the wastewater sector. Incorporating anaerobic digestion at wastewater treatment plants with flow rates greater than $5 \mathrm{mgd}\left(18,900 \mathrm{~m}^{3} / \mathrm{d}\right)$, as in Case AD-3, to produce and utilize biogas would further reduce energy needs and can be gradually implemented as many treatment plants undergo replacement or significant upgrades in the coming years.

Implementation of biosolids incineration with electricity generation might also slow or mitigate energy consumption for the wastewater sector. Through biosolids incineration, wastewater facilities 
can turn biosolids handling and disposal issues into possible cost savings through electricity generation for wastewater treatment plant use or sale to the electric power grid.

Because of the potential energy savings, the federal, state, and local governments might consider policy changes or incentives that can be implemented to help wastewater treatment plants utilize anaerobic digestion for biosolids treatment and install biogas utilization equipment to reduce energy costs and demand. The U.S. EPA might also consider explicitly designating energy recovery through biosolids incineration with electricity generation as a qualifying use of biosolids, under the beneficial use of municipal biosolids policy. These policy decisions might further encourage coupling energy recovery with adequate wastewater treatment.

The federal government can support increased biogas and biosolids energy generation through its existing assistance programs. The EPA's state revolving fund, the Department of Agriculture's Rural Utility Service loan and grant program, and Department of Housing and Urban Development's Community Development Block Grants can prioritize energy efficiency and biogas and biosolids electricity generation in administering financial aid to wastewater districts. Government at all levels (federal, state, and local), including public utilities, can encourage efficiency by encouraging or requiring energy audits at wastewater treatment plants and energy awareness campaigns for wastewater operators. EPRI publishes a manual to guide energy audits at wastewater treatment plants, including process, pumping, and facilities (heating, ventilation, and air conditioning and lighting) audits [26].

Including treatment process, biogas and biosolids production and utilization, and energy audit questions in the quadrennial CWNS will improve understanding about energy use by wastewater treatment plants and allow government agencies and professional organizations to target those facilities with the greatest energy savings potential. Because the CWNS already exists, adding these additional questions requires minimal cost and effort. Such data collection would greatly aid research projects to decrease the wide range of potential energy savings from anaerobic digestion and biosolids incineration, making the results more pertinent and useful in a policy context.

\section{Conclusions}

The interrelationship between energy and water and the organic content of wastewater can encourage energy recovery operations from many possible sources, including municipal wastewater treatment facilities. Implementing anaerobic digestion with biogas utilization in varying degrees nationwide can reduce electricity consumption for wastewater treatment by 2.6 to $27 \%$. Through incorporation of anaerobic digestion with biogas utilization and biosolids incineration with electricity generation, wastewater utilities can reduce electricity consumption by 4.7 to $83 \%$ in the state of Texas. These wide ranges in electricity percent savings for the wastewater sector are due to the difference in wastewater flows analyzed in each individual scenario of our analysis. In this case, the low end represents use of existing energy recovery processes and the high end illustrates potential energy recovery from widespread implementation of anaerobic digestion with biogas utilization and/or biosolids incineration with electricity generation. Changing organic content of wastewater-either increasing with lower wastewater flows that concentrate wastes or decreasing with improved waste management —introduces additional uncertainty into these energy recovery estimates. Future work 
should analyze energy recovery from biosolids incineration for the entire United States, since our results for the state of Texas show that electricity generation from biosolids incineration is feasible and significant. With rising concerns about emerging water contaminants such as pharmaceuticals and personal care products, wastewater treatment is likely to become more energy-intensive in the future. These energy recovery options have the potential to offset increases in electricity consumption necessary to uphold stricter wastewater treatment standards. Energy recovery from wastewater treatment plants presents an opportunity for successful and sustainable management of energy and water resources.

\section{Acknowledgements}

This work was supported by the Center for International Energy and Environmental Policy at the University of Texas at Austin. The authors would like to thank Desmond Lawler in the Department of Civil, Architectural, and Environmental Engineering at the University of Texas at Austin for his insightful comments and suggestions.

\section{References and Notes}

1. Stillwell, A.S.; King, C.W.; Webber, M.E.; Duncan, I.J.; Hardberger, A. Energy-Water Nexus in Texas; Environmental Defense Fund, University of Texas at Austin: Austin, TX, USA, 2009.

2. Energy Conservation in Wastewater Treatment Facilities Manual of Practice; Water Environment Federation: Alexandria, VA, USA, 1997; pp. 1-142.

3. Westerhoff, P.; Yoon, Y.; Snyder, S.; Wert, E. Fate of Endocrine-Disruptor, Pharmaceutical, and Personal Care Product Chemicals during Simulated Drinking Water Treatment Processes. Environ. Sci. Technol. 2005, 39, 6649-6663.

4. Zwiener, C.; Frimmel, F.H. Oxidative Treatment of Pharmaceuticals in Water. Water Res. 2000, $34,1881-1885$.

5. Means, E.G. Water and Wastewater Industry Energy Efficiency: A Research Roadmap; Water Research Foundation: Denver, CO, USA, 2004; p. 28; Available online: http://www. waterresearchfoundation.org/research/topicsandprojects/execSum/2923.aspx (accessed on 9 October 2009).

6. Hoppock, D.C.; Webber, M.E. Energy Needs and Opportunities at POTWs in the United States. In Proceedings of the American Society of Mechanical Engineers (ASME) 2nd International Conference on Energy Sustainability, Jacksonville, FL, USA, 10-14 August 2008.

7. California's Water-Energy Relationship; CEC-700-2005-011-SF; California Energy Commission: Sacramento, CA, USA, 2005; Available online: http://www.energy.ca.gov/2005publications/CEC700-2005-011/CEC-700-2005-011-SF.PDF (accessed on 8 October 2009).

8. Primer for Municipal Wastewater Treatment Systems; Office of Wastewater Management, Environmental Protection Agency: Washington, DC, USA, 2004; Available online: http://www.epa.gov/npdes/pubs/primer.pdf (accessed on 8 October 2009).

9. Metcalf \& Eddy, Inc. Wastewater Engineering: Treatment and Reuse, 4th ed.; McGraw Hill: Boston, MA, USA, 2003; pp. 1345-1446. 
10. Burton, F.L. Water and Wastewater Industries: Characteristics and Energy Management Opportunities; Burton Environmental Engineering, Electric Power Research Institute Community Environmental Center: Los Altos, CA, USA, 1996.

11. Ekama, G.A.; Sotemann, S.W.; Wentzel, M.C. Biodegradability of activated sludge organics under anaerobic conditions. Water Res. 2007, 41, 244-252.

12. Rosso, D.; Stenstrom, M.K. The carbon-sequestration potential of municipal wastewater treatment. Chemosphere 2008, 70, 1468-1475.

13. Stoica, A.; Sandberg, M.; Holby, O. Energy use and recovery strategies within wastewater treatment and sludge handling at pulp and paper mills. Bioresource Technol. 2009, 100, 3497-3505.

14. Opportunities for and Benefits of Combined Heat and Power at Wastewater Treatment Facilities; Eastern Research Group and Energy and Environmental Analysis, U.S. Environmental Protection Agency: Washington, DC, USA, 2007; pp. ii-10; Available online: http://www.epa.gov/CHP/documents/wwtf_opportunities.pdf (accessed on 8 October 2009).

15. Biosolids Recycling: Beneficial Technology for a Better Environment; Environmental Protection Agency: Washington, DC, USA, 1984; Available online: http://www.epa.gov/owm/mtb/ biosolids/bio1-3.pdf (accessed on 15 October 2009).

16. Sewage Sludge. Available online: http://ec.europa.eu/environment/waste/sludge/index.htm (accessed on 19 March 2010).

17. Biosolids Technology Fact Sheet: Use of Incineration for Biosolids Management; Environmental Protection Agency: Washington, DC, USA, 2003, Available online: http://www.epa.gov/owm/mtb/incineration_biosolids.pdf (accessed on 15 October 2009).

18. WaterWorld Briefs: Black \& Veatch addresses nexus of energy, water at Hartford wastewater treatment plant. Available online: http://www.waterworld.com/index/display/articledisplay/2255210937/articles/water-utility-management/volume-2/Issue_3/Departments/briefs.html (accessed on 2 October 2009).

19. Goldstein, R.; Smith, W. Water \& Sustainability (Volume 4): U.S. Electricity Consumption for Water Supply \& Treatment-The Next Half Century; Electric Power Research Institute: Palo Alto, CA, USA, 2002, Available online: http://mydocs.epri.com/docs/public/000000000001006787.pdf (accessed on 8 October 2009).

20. 2004 Clean Watershed Needs Survey Database. Available online: http://epa.gov/cwns (accessed on 24 January 2009).

21. TCEQ Site Layers. Available online: http://www.tceq.state.tx.us/gis/sites.html (accessed on 13 June 2008).

22. EPA Envirofacts Data Warehouse. Available online: http://www.epa.gov/enviro/ (accessed on 18 November 2008).

23. Masters, G.M. Renewable and Efficient Electric Power Systems; John Wiley \& Sons: Hoboken, NJ, USA, 2004.

24. EPA CWNS 2004 Data. Available online: http://www.epa.gov/cwns/2004data.htm (accessed on 10 September 2009).

25. Lang, M.; Forste, J.; Goldstein, N.; Johnston, T.; Brandt, R. National Manual of Good Practice for Biosolids; National Biosolids Partnership: Alexandria, VA, USA, 2005. 
26. Energy Audit Manual for Water/Wastewater Facilities; Electric Power Research Institute: Palo Alto, CA, USA, 1994.

\section{Appendix}

Table A1. Energy Requirements Trickling Filter Treatment Plant [10].

\begin{tabular}{|c|c|c|c|c|c|c|}
\hline \multirow[b]{2}{*}{ Item } & \multicolumn{6}{|c|}{ Electricity used, $\mathrm{kWh} / \mathrm{day}^{1}$ (except where noted) } \\
\hline & $\begin{array}{c}1-\text {-mgd }^{2} \\
\text { plant }\end{array}$ & $\begin{array}{c}5 \text {-mgd } \\
\text { plant }\end{array}$ & $\begin{array}{c}\text { 10-mgd } \\
\text { plant }\end{array}$ & $\begin{array}{c}\text { 20-mgd } \\
\text { plant }\end{array}$ & $\begin{array}{c}\text { 50-mgd } \\
\text { plant }\end{array}$ & $\begin{array}{c}\text { 100-mgd } \\
\text { plant }\end{array}$ \\
\hline Wastewater pumping & 171 & 716 & 1,402 & 2,559 & 6,030 & 11,818 \\
\hline Screens & 2 & 2 & 2 & 3 & 6 & 11 \\
\hline Aerated grit removal & 49 & 87 & 134 & 250 & 600 & 1,200 \\
\hline Primary clarifiers & 15 & 78 & 155 & 310 & 776 & 1,551 \\
\hline Trickling filters ${ }^{3}$ & 352 & 1,319 & 2,528 & 4,686 & 11,551 & 22,826 \\
\hline Secondary clarifiers & 15 & 78 & 155 & 310 & 776 & 1,551 \\
\hline Gravity thickening & 6 & 15 & 25 & 37 & 75 & 138 \\
\hline Dissolved air floatation & $\mathrm{na}^{4}$ & na & 1,805 & 2,918 & 6,257 & 11,819 \\
\hline Aerobic digestion & 1,000 & 1,200 & na & na & na & na \\
\hline Anaerobic digestion & na & na & 1,100 & 2,100 & 5,000 & 11,000 \\
\hline Belt filter press & na & 192 & 384 & 579 & 1,164 & 2,139 \\
\hline Chlorination & 1 & 5 & 27 & 53 & 133 & 266 \\
\hline Lighting and buildings & 200 & 400 & 800 & 1,200 & 2,000 & 3,000 \\
\hline Totals & $\mathbf{1 , 8 1 1}$ & 4,892 & $\mathbf{8 , 5 1 7}$ & 15,005 & 34,368 & 67,319 \\
\hline Unit electricity use, $\mathrm{kWh} / \mathrm{mil} \mathrm{gal}^{5}$ & 1,811 & 978 & 852 & 750 & 687 & 673 \\
\hline Energy recovery (from biogas combustion) & na & na & 2,800 & 5,600 & 14,000 & 28,000 \\
\hline Net consumption ${ }^{6}$ & 1,811 & 4,892 & 5,717 & 9,405 & 20,368 & 39,319 \\
\hline Unit net electricity use $\mathrm{kWh} / \mathrm{mil}$ gal & 1,811 & 978 & 572 & 470 & 407 & 393 \\
\hline Biogas kWh/d per mgd & - & - & 280 & 280 & 280 & 280 \\
\hline
\end{tabular}

1. To convert from $\mathrm{kWh} /$ day to $\mathrm{W}$, multiply by 41.67

2. To convert from $\mathrm{mgd}$ to $\mathrm{m}^{3} / \mathrm{s}$, multiply by $4.38 \times 10^{-2}$

3 . Includes energy use required to recirculation pumping

4. Not Applicable for this size treatment plant

5. To convert from $\mathrm{kWh} /\left(\right.$ million gal) to $\mathrm{J} / \mathrm{m}^{3}$, multiply by 951.1

6. Total unit energy use less energy recovered from biogas

Table A2. Energy Requirements Activated Sludge Treatment Plant [10].

\begin{tabular}{|c|c|c|c|c|c|c|}
\hline \multirow[b]{2}{*}{ Item } & \multicolumn{6}{|c|}{ Electricity used, $\mathrm{kWh} \mathrm{day}^{1}$ (except where noted) } \\
\hline & $\begin{array}{c}1-\text { mgd }^{2} \\
\text { plant }\end{array}$ & $\begin{array}{l}\text { 5-mgd } \\
\text { plant }\end{array}$ & $\begin{array}{c}\text { 10-mgd } \\
\text { plant }\end{array}$ & $\begin{array}{c}\text { 20-mgd } \\
\text { plant }\end{array}$ & $\begin{array}{c}\text { 50-mgd } \\
\text { plant }\end{array}$ & $\begin{array}{c}\text { 100-mgd } \\
\text { plant }\end{array}$ \\
\hline Wastewater pumping & 171 & 716 & 1,402 & 2,559 & 6,030 & 11,818 \\
\hline Screens & 2 & 2 & 2 & 3 & 6 & 11 \\
\hline Aerated grit removal & 49 & 87 & 134 & 250 & 600 & 1,200 \\
\hline Primary clarifiers & 15 & 78 & 155 & 310 & 776 & 1,551 \\
\hline Aeration (diffused air) & 532 & 2,660 & 5,320 & 10,640 & 26,600 & 53,200 \\
\hline
\end{tabular}


Table A2. Cont.

\begin{tabular}{|c|c|c|c|c|c|c|}
\hline \multirow[b]{2}{*}{ Item } & \multicolumn{6}{|c|}{ Electricity used, $\mathrm{kWh} / \mathrm{day}^{1}$ (except where noted) } \\
\hline & $\begin{array}{c}\text { 1-mgd } \\
\text { plant }\end{array}$ & $\begin{array}{l}\text { 5-mgd } \\
\text { plant }\end{array}$ & $\begin{array}{l}\text { 10-mgd } \\
\text { plant }\end{array}$ & $\begin{array}{l}\text { 20-mgd } \\
\text { plant }\end{array}$ & $\begin{array}{c}\text { 50-mgd } \\
\text { plant }\end{array}$ & $\begin{array}{c}\text { 100-mgd } \\
\text { plant }\end{array}$ \\
\hline Return sludge pumping & 45 & 213 & 423 & 724 & 1,627 & 3,131 \\
\hline Secondary clarifiers & 15 & 78 & 155 & 310 & 776 & 1,551 \\
\hline Gravity thickening & 6 & 15 & 25 & 37 & 75 & 138 \\
\hline Dissolved air floatation & $\mathrm{na}^{3}$ & na & 1,805 & 2,918 & 6,257 & 11,819 \\
\hline Aerobic digestion & 1,200 & 2,400 & na & na & na & na \\
\hline Anaerobic digestion & na & na & 1,400 & 2,700 & 6,500 & 13,000 \\
\hline Belt filter press & na & 192 & 384 & 579 & 1,164 & 2,139 \\
\hline Chlorination & 1 & 5 & 27 & 53 & 133 & 266 \\
\hline Lighting and buildings & 200 & 400 & 800 & 1,200 & 2,000 & 3,000 \\
\hline Totals & 2,236 & 6,846 & 12,032 & 22,283 & 52,544 & 102,824 \\
\hline 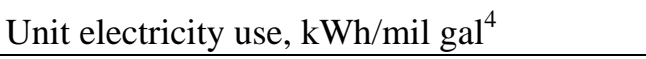 & 2,236 & 1,369 & 1,203 & 1,114 & 1,051 & 1,028 \\
\hline Energy recovery (from biogas combustion) & na & na & 3,500 & 7,000 & 17,500 & 35,000 \\
\hline Net consumption ${ }^{5}$ & 2,236 & 6,779 & 8,532 & 15,283 & 35,044 & 67,824 \\
\hline Unit Net electricity use $\mathrm{kWh} / \mathrm{mil}$ gal & 2,236 & 1,356 & 853 & 764 & 701 & 678 \\
\hline Biogas $\mathrm{kWh} / \mathrm{d}$ per mgd & & & 350 & 350 & 350 & 350 \\
\hline
\end{tabular}

1. To convert from $\mathrm{kWh} /$ day to $\mathrm{W}$, multiply by 41.67

2. To convert from $\mathrm{mgd}$ to $\mathrm{m}^{3} / \mathrm{s}$, multiply by $4.38 \times 10^{-2}$

3. Not Applicable for this size treatment plant

4. To convert from $\mathrm{kWh} /$ (million gal) to $\mathrm{J} / \mathrm{m}^{3}$, multiply by 951.1

5. Total unit energy use less energy recovered from biogas

Table A3. Energy Requirements Advanced Treatment Plant without Nitrification [10].

\begin{tabular}{|c|c|c|c|c|c|c|}
\hline \multirow[b]{2}{*}{ Item } & \multicolumn{6}{|c|}{ Electricity used, $\mathrm{kWh} / \mathrm{day}^{1}{ }$ (except where noted) } \\
\hline & $\begin{array}{l}1-\text { mgd }^{2} \\
\text { plant }\end{array}$ & $\begin{array}{c}\text { 5-mgd } \\
\text { plant }\end{array}$ & $\begin{array}{l}\text { 10-mgd } \\
\text { plant }\end{array}$ & $\begin{array}{l}\text { 20-mgd } \\
\text { plant }\end{array}$ & $\begin{array}{l}\text { 50-mgd } \\
\text { plant }\end{array}$ & $\begin{array}{c}\text { 100-mgd } \\
\text { plant }\end{array}$ \\
\hline Wastewater pumping & 171 & 716 & 1,402 & 2,559 & 6,030 & 11,818 \\
\hline Screens & 2 & 2 & 2 & 3 & 6 & 11 \\
\hline Aerated grit removal & 49 & 87 & 134 & 250 & 600 & 1,200 \\
\hline Primary clarifiers & 15 & 78 & 155 & 310 & 776 & 1,551 \\
\hline Aeration (diffused air) & 532 & 2,660 & 5,320 & 10,640 & 26,600 & 53,200 \\
\hline Return sludge pumping & 45 & 213 & 423 & 724 & 1,627 & 3,131 \\
\hline Secondary clarifiers & 15 & 78 & 155 & 310 & 776 & 1,551 \\
\hline Chemical addition & 80 & 290 & 552 & 954 & 2,187 & 4,159 \\
\hline Filter feed pumping & 143 & 445 & 822 & 1,645 & 3,440 & 6,712 \\
\hline Filtration & 137 & 247 & 385 & 709 & 1,679 & 3,295 \\
\hline Gravity thickening & 6 & 15 & 25 & 37 & 75 & 138 \\
\hline Dissolved air floatation & $\mathrm{na}^{3}$ & na & 2,022 & 3,268 & 7,008 & 13,273 \\
\hline Aerobic digestion & 1,200 & 2,400 & na & na & na & na \\
\hline Anaerobic digestion & na & na & 1,400 & 2,700 & 6,500 & 13,000 \\
\hline Belt filter press & na & 228 & 457 & 689 & 1,385 & 2,545 \\
\hline
\end{tabular}

Table A3. Cont. 


\begin{tabular}{|c|c|c|c|c|c|c|}
\hline \multirow[b]{2}{*}{ Item } & \multicolumn{6}{|c|}{ Electricity used, kWh/day ${ }^{1}$ (except where noted) } \\
\hline & $\begin{array}{c}1 \text {-mgd } \\
\text { plant }\end{array}$ & $\begin{array}{c}\text { 5-mgd } \\
\text { plant }\end{array}$ & $\begin{array}{c}\text { 10-mgd } \\
\text { plant }\end{array}$ & $\begin{array}{c}\text { 20-mgd } \\
\text { plant }\end{array}$ & $\begin{array}{c}\text { 50-mgd } \\
\text { plant }\end{array}$ & $\begin{array}{c}\text { 100-mgd } \\
\text { plant }\end{array}$ \\
\hline Chlorination & 1 & 5 & 27 & 53 & 133 & 266 \\
\hline Lighting and buildings & 200 & 400 & 800 & 1,200 & 2,000 & 3,000 \\
\hline Totals & 2,596 & 7,864 & 14,081 & 26,051 & 60,822 & 118,814 \\
\hline Unit electricity use, $\mathrm{kWh} / \mathrm{mil} \mathrm{gal}^{4}$ & 2,596 & 1,573 & 1,408 & 1,303 & 1,216 & 1,188 \\
\hline Energy recovery (from biogas combustion) & na & na & 3,500 & 7000 & 17,500 & 35,000 \\
\hline Net consumption $^{5}$ & 2,596 & 7,964 & 10,581 & 19,051 & 43,322 & 83,814 \\
\hline Unit net electricity use $\mathrm{kWh} / \mathrm{mil}$ gal & 2,596 & 1,573 & 1,058 & 953 & 866 & 838 \\
\hline Biogas kWh/d per mgd & & & 350 & 350 & 350 & 350 \\
\hline
\end{tabular}

1. To convert from $\mathrm{kWh} /$ day to $\mathrm{W}$, multiply by 41.67

2. To convert from $\mathrm{mgd}$ to $\mathrm{m}^{3} / \mathrm{s}$, multiply by $4.38 \times 10^{-2}$

3. Not Applicable for this size treatment plant

4. To convert from $\mathrm{kWh} /\left(\right.$ million gal) to $\mathrm{J} / \mathrm{m}^{3}$, multiply by 951.1

5. Total unit energy use less energy recovered from biogas

Table A4. Energy Requirements Advanced Treatment Plant with Nitrification [10].

\begin{tabular}{|c|c|c|c|c|c|c|}
\hline \multirow[b]{2}{*}{ Item } & \multicolumn{6}{|c|}{ Electricity used, $\mathrm{kWh} / \mathrm{day}^{1}$ (except where noted) } \\
\hline & $\begin{array}{c}1-\text {-mgd }^{2} \\
\text { plant }\end{array}$ & $\begin{array}{l}\text { 5-mgd } \\
\text { plant }\end{array}$ & $\begin{array}{l}\text { 10-mgd } \\
\text { plant }\end{array}$ & $\begin{array}{l}\text { 20-mgd } \\
\text { plant }\end{array}$ & $\begin{array}{c}\text { 50-mgd } \\
\text { plant }\end{array}$ & $\begin{array}{c}\text { 100-mgd } \\
\text { plant }\end{array}$ \\
\hline Wastewater pumping & 171 & 716 & 1,402 & 2,559 & 6,030 & 11,818 \\
\hline Screens & 2 & 2 & 2 & 3 & 6 & 11 \\
\hline Aerated grit removal & 49 & 87 & 134 & 250 & 600 & 1,200 \\
\hline Primary clarifiers & 15 & 78 & 155 & 310 & 776 & 1,551 \\
\hline Aeration (diffused air) & 532 & 2,660 & 5,320 & 10,640 & 26,600 & 53,200 \\
\hline Biological nitrification & 346 & 1,724 & 3,446 & 6,818 & 16,936 & 33,800 \\
\hline Return sludge pumping & 54 & 256 & 508 & 869 & 1,952 & 3,757 \\
\hline Secondary clarifiers & 15 & 78 & 155 & 310 & 776 & 1,551 \\
\hline Chemical addition & 80 & 290 & 552 & 954 & 2,187 & 4,159 \\
\hline Filter feed pumping & 143 & 445 & 822 & 1,645 & 3,440 & 6,712 \\
\hline Filtration & 137 & 247 & 385 & 709 & 1,679 & 3,295 \\
\hline Gravity thickening & 6 & 15 & 25 & 37 & 75 & 138 \\
\hline Dissolved air floatation & $\mathrm{na}^{3}$ & na & 2,022 & 3,268 & 7,008 & 13,273 \\
\hline Aerobic digestion & 1,200 & 2,400 & na & na & na & na \\
\hline Anaerobic digestion & na & na & 1,700 & 3,200 & 7,800 & 15,600 \\
\hline Belt filter press & na & 228 & 457 & 689 & 1,385 & 2,545 \\
\hline Chlorination & 1 & 5 & 27 & 53 & 133 & 266 \\
\hline Lighting and buildings & 200 & 400 & 800 & 1,200 & 2,000 & 3,000 \\
\hline
\end{tabular}


Table A4. Cont.

\begin{tabular}{|l|c|c|c|c|c|c|}
\hline \multirow{2}{*}{\multicolumn{1}{|c|}{ Item }} & \multicolumn{5}{|c|}{ Electricity used, kWh/day (except where noted) } \\
\cline { 2 - 7 } & $\begin{array}{c}\mathbf{1 - m g d} \\
\text { plant }\end{array}$ & $\begin{array}{c}\mathbf{5} \text {-mgd } \\
\text { plant }\end{array}$ & $\begin{array}{c}\mathbf{1 0 - m g d} \\
\text { plant }\end{array}$ & $\begin{array}{c}\mathbf{2 0} \text {-mgd } \\
\text { plant }\end{array}$ & $\begin{array}{c}\mathbf{5 0 - m g d} \\
\text { plant }\end{array}$ & $\begin{array}{c}\mathbf{1 0 0 - m g d} \\
\text { plant }\end{array}$ \\
\hline Totals & $\mathbf{2 , 9 5 1}$ & $\mathbf{9 , 6 3 1}$ & $\mathbf{1 7 , 9 1 2}$ & $\mathbf{3 3 , 5 1 4}$ & $\mathbf{7 9 , 3 8 3}$ & $\mathbf{1 5 5 , 5 4 0}$ \\
\hline \hline Unit electricity use, $\mathrm{kWh} /$ mil gal $^{4}$ & 2,951 & 1,926 & 1,791 & 1,676 & 1,588 & 1,558 \\
\hline Energy recovery (from biogas combustion) & na & na & 3,500 & 7,000 & 17,500 & 35,000 \\
\hline Net consumption & 2,951 & 9,631 & 14,412 & 26,514 & 61,883 & 120,540 \\
\hline Unit net electricity use kWh/mil gal & 2,951 & 1,926 & 1,441 & 1,326 & 1,238 & 1,208 \\
\hline Biogas kWh/d per mgd & - & - & 350 & 350 & 350 & 350 \\
\hline
\end{tabular}

1. To convert from $\mathrm{kWh} /$ day to $\mathrm{W}$, multiply by 41.67

2. To convert from $\mathrm{mgd}$ to $\mathrm{m}^{3} / \mathrm{s}$, multiply by $4.38 \times 10^{-2}$

3. Not Applicable for this size treatment plant

4. To convert from $\mathrm{kWh} /\left(\right.$ million gal) to $\mathrm{J} / \mathrm{m}^{3}$, multiply by 951.1

5. Total unit energy use less energy recovered from biogas

(C) 2010 by the authors; licensee Molecular Diversity Preservation International, Basel, Switzerland. This article is an open-access article distributed under the terms and conditions of the Creative Commons Attribution license (http://creativecommons.org/licenses/by/3.0/). 